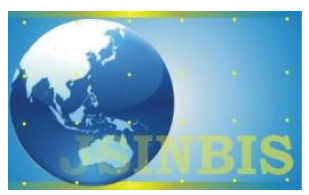

\title{
Penerapan ANP-TOPSIS untuk Pengukuran Kinerja Human ResourcesProcurement Section
}

\author{
Moh Ramdhan Arif Kaluku ${ }^{a^{*}}$, Ferry Jie ${ }^{\mathrm{b}}$ \\ ${ }^{\mathrm{a} J u r u s a n}$ Teknik Informatika, Universitas Negeri Gorontalo \\ ${ }^{\mathrm{b}}$ Business IT \& Logistics Unit MRIT University, Melbourne
}

Naskah Diterima : 13 Mei 2015; Diterima Publikasi : 13 Juli 2015

\begin{abstract}
One practice is important in a company's performance is in the process of procurement. Performance of human resources in a company shows a measure of the quality of work and is used as a measure to observe the performance levels of employees in a company. The level of underperformance will have an impact on the quality of jobs that will be performed that could have a serious impact on the company. It is necessary to develop a human resources performance measurement using ANP method and TOPSIS, the procurement section of the company. This study aims to assist in the decision making process and seek alternative solutions to address the issues in order to measure the level of performance of each employee. In this study, the method used to obtain the ANP normal weight that will be used for calculations on TOPSIS method. The input parameters in the weighting process ANP is also very affecting for ranking process to be performed on TOPSIS. The input parameter is the ratio of any existing KPI indicators on procurement section. The results showed that the proposed method can be used to build a predictive performance measurement on procurement human resources section. From the research the highest performance values obtained on procurement section is 0.6936 while the lowest value was 0.3584 .
\end{abstract}

Keywords: ANP; TOPSIS; KPI; Human Resources; Procurement Section

\begin{abstract}
Abstrak
Salah satu praktek kinerja penting dalam suatu perusahaan adalah pada proses pengadaan. Kinerja human resources pada suatu perusahaan menunjukkan ukuran kualitas suatu pekerjaan dan digunakan sebagai ukuran untuk mengamati tingkat kinerja dari pegawai dalam suatu perusahaan. Tingkat kinerja yang kurang akan berdampak pada kualitas perkerjaan yang akan dilakukan yang bisa berdampak serius pada perusahaan. Maka perlu dikembangkan sebuah pengukuran kinerja human resources dengan menggunakan metode ANP dan TOPSIS, pada procurement section dalam perusahaan. Penelitian ini bertujuan untuk membantu dalam proses pengambilan keputusan dan mencari alternatif solusi untuk mengatasi permasalahan untuk mengukur tingkat kinerja dari setiap pegawai. Pada penelitian ini, metode ANP digunakan untuk memperoleh bobot normal yang nantinya akan digunakan untuk perhitungan pada metode TOPSIS. Parameter masukan pada proses pembobotan ANP juga sangat mempengaruhi untuk proses perangkingan yang akan dilakukan pada TOPSIS. Adapun parameter inputnya adalah perbandingan setiap indikator KPI yang ada padaprocurement section tersebut. Hasil penelitian menunjukkan bahwa metode yang diusulkan dapat digunakan untuk membangun sebuah prediksi pengukuran kinerja human resources padaprocurement section. Dari penelitian diperoleh nilai kinerja tertinggi pada procurement sectionadalah 0,6936 sedangkan nilai terendah adalah 0,3584 .
\end{abstract}

Keywords: ANP; TOPSIS; KPI; Sumberdaya Manusia; Procurement Section

\section{Pendahuluan}

Tekanan ekonomi yang semakin kompetitif belakangan ini, menjadi sangat penting bagi organisasi untuk menyeimbangkan kinerja dan kualitas. Karena keberhasilan perusahaan dalam proses bisnisnya tidak lepas dari sistem human resources (HR) yang baik yang ada di dalamnya. Alokasi HR merupakan proses inti dari sebuah sistem informasi (Silva dan Costa, 2013). Pada perkembangan ekonomi yang semakin pesat dewasa ini menyebabkan banyak perusahaan berlomba- lomba untuk meningkatkan keuntungannya, baik dari segi kualitas, kuantitas serta pelayanan yang diberikan kepada konsumen. Saat ini kinerja dari karyawan atau HR yang ada sangat penting bagi perusahaan untuk mengoptimalkan keuntungan perusahaan itu sendiri. Praktek human resources management (HRM) secara efektif dapat menyelaraskan organisasi, kelompok dan individu (Buller dan Mc Evoy, 2012). Keselarasan tersebut terkait erat dengan pembentukan karakter manusia dan karakter sosial, baik untuk mencapai dan mempertahankan kinerja yang unggul.

*) Penulis korespondensi: aliaskaluku@ gmail.com 
Procurement section merupakan salah satu proses penting dalam praktek kerja di dalam perusahaan, pada procurement section adalah penting untuk tetap mempertahanan kinerja dari pegawai pada bagian itu. Karena procurement section nantinya yang akan memasok dan memilih bahan baku untuk disalurkan pada bagian produksi. Pelayanan dan kinerja yang baik merupakan salah satu faktor utama yang sangat penting yang ada dalam proses bisnis (Parmenter, 2007). Untuk menilai kinerja dari karyawan sangatlah sulit dan subyektif, karena tidak adanya indikator kinerja yang terukur dan obyektif. Sehingga perlu didukung dengan identifikasi Key Performance Indicator (KPI) secara tepat yang berfungsi untuk mengukur kemajuan sesuai dengan sasaran dari organisasi itu untuk menentukan penilai kinerja HR (Parmenter, 2007; Caiet al., 2009).

Analytic Network Process (ANP) digunakan untuk pengambilan keputusan multikriteria. ANP merupakan kerangka umum yang digunakan untuk menangani masalah keputusan pembuat asumsi tentang independensi dari kelompok atau elemen (Saaty, 1999). Metode TOPSIS digunakan untuk memilih alternative yang secara bersamaan memiliki jarak terpendek dari solusi ideal positif dan jarak terjauh dari solusi ideal negatif (Behzadian et al., 2012; Kusumadewi et al., 2006).

$\mathrm{Wu}$ et al. (2010) menjelaskan penggunaan ANP dan Technique for Order Preference by Similarity to an Ideal Solution (TOPSIS) memiliki kontribusi yang terletak pada implementasi praktis untuk mengoptimalkan strategi. Penggabungan teknik ANP untuk menentukan bobot relative beberapa evaluasi kriteria, dan pendekatan TOPSIS yang digunakan untuk menentukan peringkat yang bersaing dalam hal kinerja secara keseluruhan (Shyur, 2006).

Suatu rangkaian aktifitas perusahaan tidak dapat terlaksana tanpa ada dukungan dari human resources (HR) yang kompeten dalam menjalankan aktifitas dari perusahaan itu. HR yang tidak kompeten menyebabkan kemunduran bagi aktifitas perekonomian perusahaan. Untuk itu kinerja karyawan dari perusahaan itu harus optimal. Key Performance Indicator (KPI) dapat digunakan untuk mengukur pencapaian kinerja dan mengukur penilaian hasil pekerjaan HR. Dimana KPI menjadi indikator yang digunakan untuk pengukuran kinerja HR.

Perlu adanya hubungan yang baik antara HR dan praktek pada procurementsection agar meningkatkan hasil bisnis. Untuk menghasilkan kualitas dan kuantitas yang baik, dilakukan penilaian pada kinerja HR terhadap procurement section. Adapun penilaian dilakukan dengan menentukan setiap indikator KPI yang ada pada procurement section. Hal Ini juga akan membantu untuk mengidentifikasi hubungan yang signifikan antara HR dan procurement section dalam melakukan pengukuran kinerja. Diharapkan bahwa hubungan keduanya akan meningkatkan praktek procurement section dan dengan demikian memberikan kesempatan yang lebih besar untuk peningkatan kinerja.

Untuk itu perlu dilakukan pengukuran KPI human resources (HR) pada procurement sectionkarena procurement sectionmerupakan bagian terpenting dalam proses kinerja di dalam perusahaan. Sebuah metodologi berbasis ANP-TOPSIS digunakan untuk mengukur Kinerja HR pada procurement section dimana identifikasi KPI dari data yang dianalisis dikumpulkan berupa faktor-faktor yang dapat mempengaruhi kinerja HR. Metode ANP berbasis evaluasi kinerja digunakan untuk mengukur bobot kriteria yang ada di HR pada procurement section. Selanjutnya data yang diperoleh dari pembobotan dengan menggunakan ANP diolah menggunakan metode TOPSIS untuk penilaian berdasarkan alternatif potensial.

\section{KerangkaTeori}

\subsection{Analytic Network Process (ANP)}

ANP merupakan generalisasi dari Analytic Hierarchy Process (AHP), dengan mempertimbangkan ketergantungan antara unsurunsur hirarki. Banyak masalah keputusan tidak dapat terstruktur secara hirarki karena mereka melibatkan interaksi dan ketergantungan dengan elemen tingkat yang lebih tinggi dalam hirarki, pada elemen tingkat yang lebih rendah. Oleh karena itu, ANP yang diwakili oleh jaringan, bukan hirarki dapat mengatasi masalah tersebut. ANP adalah cara logis untuk menangani ketergantungan (Saaty, 1999; Saaty, 2008).

Model dari metode ANP yaitu berupa jaringan sehingga dapat diketahui saling keterkaitan antara setiap elemen yang ada pada satu kriteria yang sama, ataupun terhadap elemen-elemen yang berbeda kriteria. Adapun Model ANP seperti pada Gambar 1 :

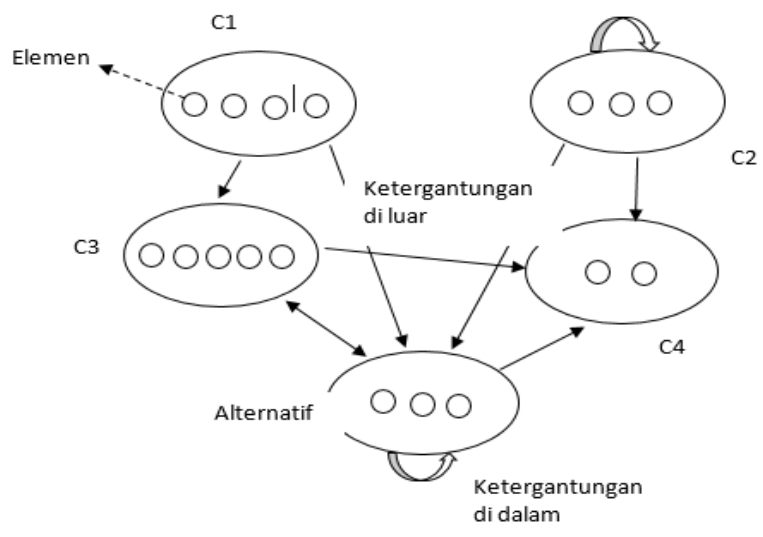

Gambar 1. ModelANP (Saaty, 1999)

Pada dasarnya, prosedur atau langkah-langkah dalam metode ANP yang digunakan meliputi: 
1. Mendefinisikan masalah dan menentukan solusi yang diinginkan, lalu menyusun jaringan dari permasalahan yang dihadapi.

2. Menentukan prioritas elemen

- Menentukan prioritas elemen dengan membuat perbandingan berpasangan berdasarkan sesuai dengan kriteria yang diberikan dengan mengelompokan dalam komponen yang sama.

- Dalam model ANP, langkah yang harus dilakukan adalah mengetahui suatu tingkat kepentingan terhadap kriteria ANP untuk perbandingan kriteria dalam seluruh sistem. Langkah ini dilakukan melalui matriks perbandingan berpasangan.

- Nilai numerik pada seluruh perbandingan diperoleh dari skala perbandingan 1 sampai 9 yang telah ditetapkan oleh Saaty, seperti pada tabel berikut ini.

Tabel 1. Skala Matriks Perbandingan Berpasangan (Saaty, 1999)

\begin{tabular}{|c|c|c|}
\hline $\begin{array}{c}\text { Nilai } \\
\text { Kepentingan }\end{array}$ & Definisi & Keterangan \\
\hline 1 & $\begin{array}{l}\text { Sama } \\
\text { penting }\end{array}$ & $\begin{array}{l}\text { Kedua elemen sama } \\
\text { pentingnya }\end{array}$ \\
\hline 3 & $\begin{array}{l}\text { Sedikit } \\
\text { lebih } \\
\text { penting }\end{array}$ & $\begin{array}{l}\text { Elemen yang satu } \\
\text { sedikit lebih penting } \\
\text { daripada elemen yang } \\
\text { lainnya }\end{array}$ \\
\hline 5 & $\begin{array}{l}\text { Cukup } \\
\text { penting }\end{array}$ & $\begin{array}{l}\text { Pengalaman dan } \\
\text { keputusan menunjukkan } \\
\text { kesukaan atas satu } \\
\text { aktifitas lebih dari yang } \\
\text { lain }\end{array}$ \\
\hline 7 & $\begin{array}{l}\text { Lebih } \\
\text { penting }\end{array}$ & $\begin{array}{l}\text { Pengalaman dan } \\
\text { keputusan menunjukkan } \\
\text { kesukaan yang kuat atas } \\
\text { satu aktifitas lebih dari } \\
\text { yang lain. }\end{array}$ \\
\hline 9 & $\begin{array}{l}\text { Mutlak } \\
\text { lebih } \\
\text { penting }\end{array}$ & $\begin{array}{l}\text { Satu elemen mutlak lebih } \\
\text { disukai dibandingkan } \\
\text { dengan pasangannya, } \\
\text { pada tingkat keyakinan } \\
\text { tertinggi. }\end{array}$ \\
\hline $2,4,6,8$ & Nilai antara & $\begin{array}{l}\text { Nilai-nilai antara dua } \\
\text { pertimbangan yang } \\
\text { berdekatan }\end{array}$ \\
\hline Reciprocal & Kebalikan & $\begin{array}{l}\text { Jika untuk elemen i } \\
\text { mempunyai nilai } \\
\text { perbandingan } 1 \text { sampai } \\
9 \text { apabila dibandingkan } \\
\text { dengan elemen j, maka } \\
\text { j mempunyai nilai } \\
\text { kebalikannya jika } \\
\text { dibanding dengan i }\end{array}$ \\
\hline
\end{tabular}

3. Menghitung bobot elemen

Dalam pembuatan keputusan, penting untuk mengetahui seberapa baik konsistensi yang ada karena kita tidak menginginkan keputusan berdasarkan pertimbangan dengan konsistensi yang rendah.

4. Hitung Consistency Index (CI):

$$
\mathrm{CI}:(\lambda \text { maks-n) / (n-1) }
$$

5. Hitung Rasio Konsistensi / Consistency Ratio (CR)

$$
\mathrm{CR}: \mathrm{CI} / \mathrm{IR}
$$

Dengan CR : Consistency Ratio CI : Consistency Index

IR : Indeks Random Consistency

Index Random dapat dilihat pada Tabel 2

Tabel 2 Index Random

\begin{tabular}{cc}
\hline Ukuran Matrix $(\mathrm{N})$ & Nilai IR \\
\hline 1 & 0,00 \\
2 & 0,00 \\
3 & 0,58 \\
4 & 0,90 \\
5 & 1,12 \\
6 & 1,24 \\
7 & 1,32 \\
8 & 1,41 \\
9 & 1,45 \\
10 & 1,49 \\
\hline
\end{tabular}

Bila matriks matriks perbandingan berpasangan (pair-wise comparison) dengan nilai CR lebih kecil dari 0,100 maka ketidakkonsistenan pendapat dari decision maker masih dapat diterima jika tidak maka penilaian perlu diulang.

6. Pembuatan Supermatrix

Supermatriks merupakan hasil vektor prioritas dari perbandingan berpasangan

antar cluster, kriteria, dan alternatif. Supermatriks terdiri dari tiga tahap, yaitu:

1. Tahap Unweighted Supermatrix

Unweighted Supermatrix diperoleh

berdasarkan perbandingan berpasangan antar cluster, kriteria dan alternatif dengan cara memasukan vector prioritas (eigen vector) kolom ke dalam matriks yang sesuai dengan selnya. Sehingga dapat merepresentasikan prioritas pengaruh dari elemen di sebelah kiri matriks terhadap elemen di atas matriks.

2. Tahap Weighted Supermatrix

Weighted Supermatrix diperoleh dengan cara mengalikan semua elemen pada Unweight Supermatrix dengan nilai yang terdapat dalam matriks cluster yang sesuai sehingga kolom memiliki jumlah satu.

3. Tahap Limmiting Supermatrix

Untuk memperoleh limmitingsupermatrix, weighted dengan mengkalikan supermatriks tertimbang tersebut dengan dirinya sendiri sampai beberapa kali. Ketika bobot pada setiap kolom memiliki nilai yang sama, maka limiting supermatrix sudah diperoleh.

7. Menghitung bobot keseluruhan (Global Weight) 
Bobot keseluruhan dapat diperoleh dengan mengalikan bobot subkriteria dengan kriteria. Bobot subkriteria diperoleh dari perbandingan berpasangan subkriteria, sedangkan bobot kriteria diperoleh dari perbandingan berpasangan kriteria.

\subsection{Technique for Order Preference by Similarity to an Ideal Solution (TOPSIS)}

Penggunaan hasil analisis dengan menggunakan metode TOPSIS menunjukkan bahwa indikator evaluasi kualitas yang mempengaruhi hasil evaluasi, sehingga pemilihan indicator yang tepat sangat penting (Zhuet al., 2012).

Secara umum prosedur dari metode TOPSIS mengikuti langkah-langkah sebagai berikut (Behzadian et al., 2012; Kusumadewi et al., 2006).

1. Menentukan TOPSIS membutuhkan ranking kinerja setiap alternatif $\mathrm{Ai}$ pada setiap kriteria $\mathrm{Cj}$ yang ternormalisasi.

Hal ini dapat dilihat dari rumus di bawah ini:

$$
r i j=\frac{x i j}{\sqrt{\sum_{i=1}^{m} x_{i j}^{2}}}
$$

dengan $i=1,2, \ldots . m ;$ dan $j=1,2$,

n;Ai adalah Alternatif dari suatu kegiatan;

$\mathrm{Cj}$ adalah jenis dari kriteria

2. Menghitung matriks keputusan yang ternormalisasi terbobot.dengan $\mathrm{i}=1,2, \ldots, \mathrm{m}$ dan $\mathrm{j}=1,2, \ldots, \mathrm{n}$

3. Menghitung matriks solusi ideal positif $\mathrm{A}^{+}$dan matriks solusi ideal negatif $\left.\mathrm{A}^{-} .,, \ldots,\right)$ );, ,.., );

Dimana:

adalah Max $y_{i j}$ jika $j$ adalah atribut keuntungan (benefit) Max $y_{i j}$ jika $j$ adalah atribut biaya (Cost) adalah Min $y_{i j}$ jika $j$ adalah atribut keuntungan (benefit) Min $y_{i j}$ jika $j$ adalah atribut biaya (Cost).

4. Menentukan Menghitung jarak antara nilai setiap alternatif dengan matriks solusi ideal positif dan matrik solusi ideal negatif.

Alternatif untuk solusi ideal positif.

; $\mathrm{i}=1,2, \ldots, \mathrm{m}$

Alternatif untuk solusi ideal negatif.

$; \mathrm{i}=1,2, \ldots, \mathrm{m}$

Dimana $\mathrm{D}_{\mathrm{i}}^{+}$adalah jarak terhadap solusi ideal positif untuk alternatif ke- $I$ dan $\mathrm{D}_{\mathrm{i}}^{-}$adalah jarak terhadap solusi ideal negatif.

5. Menghitung nilai preferensi untuk setiap alternatif $\left(\mathrm{V}_{\mathrm{i}}\right)$.

$\mathrm{i}=1,2, \ldots, \mathrm{m}$

Nilai preferensi adalah nilai akhir yang menjadi patokan dalam menentukan peringkat pada semua alternatif yang ada. Nilai preferensi pada suatu alternatif merupakan perbandingan antara jarak dari solusi ideal negatif dan jumlah jarak terhadap sousi ideal positif. Jika nilai $\mathrm{V}_{\mathrm{i}}$ merupakan nilai yang paling besar, menunjukkan bahwa alternatif $\mathrm{A}_{\mathrm{i}}$ telah tepat dipilih. Sehingga dapat mengurutkan peringkatnya berdasarkan nilai preferensi pada setiap alternatif.

\section{Metodologi}

Pokok utama alokasi HRM yaitu memberikan perhatian yang lebih besar terhadap pengelolaan sumber daya manusia di organisasi. Dalam mencari solusi alternative untuk proyek sistem informasi yang digunakan untuk penggabungan aspekprioritas, alokasi sumber daya manusia, perubahanlingkup, dan memperkirakan biaya. Alokasi sumber daya manusia dapat dipandang sebagai proses inti dari manajemen proyek sistem informasi. Dimana dalam organisasi, ada tuntutan agar sumber daya manusia dapat dialokasikan untuk proyek-proyek SI. Tetapi ini bukan hal yang mudah, karena jumlah proyek dan sumber daya manusia profesional yang terbatas dalam bidangnya. Sehingga perlu adanya pemrograman dinamis, untuk menetapkan sumber daya manusia untuk proyek-proyek pengembangan perangkat lunak. Dengan memperhitungkan kompleksitas setiap proyek dan kemampuan staf yang ada dan keterampilan yang dibutuhkan untuk proyek tersebut. Sebuah simulasi digunakan untuk menunjukkan model keputusan. Dengan demikian, variasi lain dapat dikembangkan untuk model ini. Diharapkan dengan variasi lain antara proyek dan tujuan alokasi bisa untuk memaksimalkan produktivitas (Silva dan Costa, 2013).

Proses pengukuran kinerja di penelitian ini diawali dengan menetapkan parameter awal, parameter ini didasarkan pada KPI yang ada pada procurement section. KPI ini nantinya aan digunakan untuk penentuan nilai perbandingan berpasangan pada ANP dan pembobotan alternatif pada TOPSIS. Adapun KPI pada procurement section seperti yang terlihat pada tabel 3 .

Tabel 3 KPI Human Resources Procurement Section

\begin{tabular}{cl}
\hline No & \multicolumn{1}{c}{ KPI } \\
\hline 1 & $\begin{array}{l}\text { Menentukan kualitas bahan yang baik (A1) } \\
\text { Menyeleksi sumber bahan baku yang baik } \\
\text { (A2) }\end{array}$ \\
3 & $\begin{array}{l}\text { Dapat menentukan kebutuhan dan } \\
\text { permintaan bahan baku (A3) } \\
\text { Menentukan waktu dan jumlah bahan baku }\end{array}$ \\
4 & $\begin{array}{l}\text { yang dibutuhkan (A4) } \\
\text { Menghemat biaya pengadaan dengan } \\
\text { kualitas bahan yang baik (A5) }\end{array}$ \\
6 & $\begin{array}{l}\text { Kecermatan dalam mengeluarkan biaya } \\
\text { operasional (A6) }\end{array}$ \\
7 & $\begin{array}{l}\text { Memilih pemasok yang lebih dekat dengan } \\
\text { pabrik. (A7) }\end{array}$ \\
8 & Bahan baku sampai tepat waktu (A8)
\end{tabular}

Penetapan KPI yang jelas berdasarkan data yang diperoleh menjadi salah satu faktor untuk mewujudkan sasaran dari perusahan yang telah ditetapkan sebelumnya. 
Dari pengukuran KPI, lalu dilakukan penentuan bobot dengan menghitung kriteria-kriteria yang ada dengan menggunakan metode ANP. Untuk mengetahui suatu tingkat kepentingan terhadap kriteria pertama-tama harus mengetahui bobot relatifnya. Dengan menentukan prioritas kriteria yang menggunakan matriks perbandingan berpasangan yang akan digunakan untuk menghitung bobot prioritas.Setelah mendapatkan bobot prioritas, penentuan peringkat akhir dilakukan dengan menggunakan metode TOPSIS.

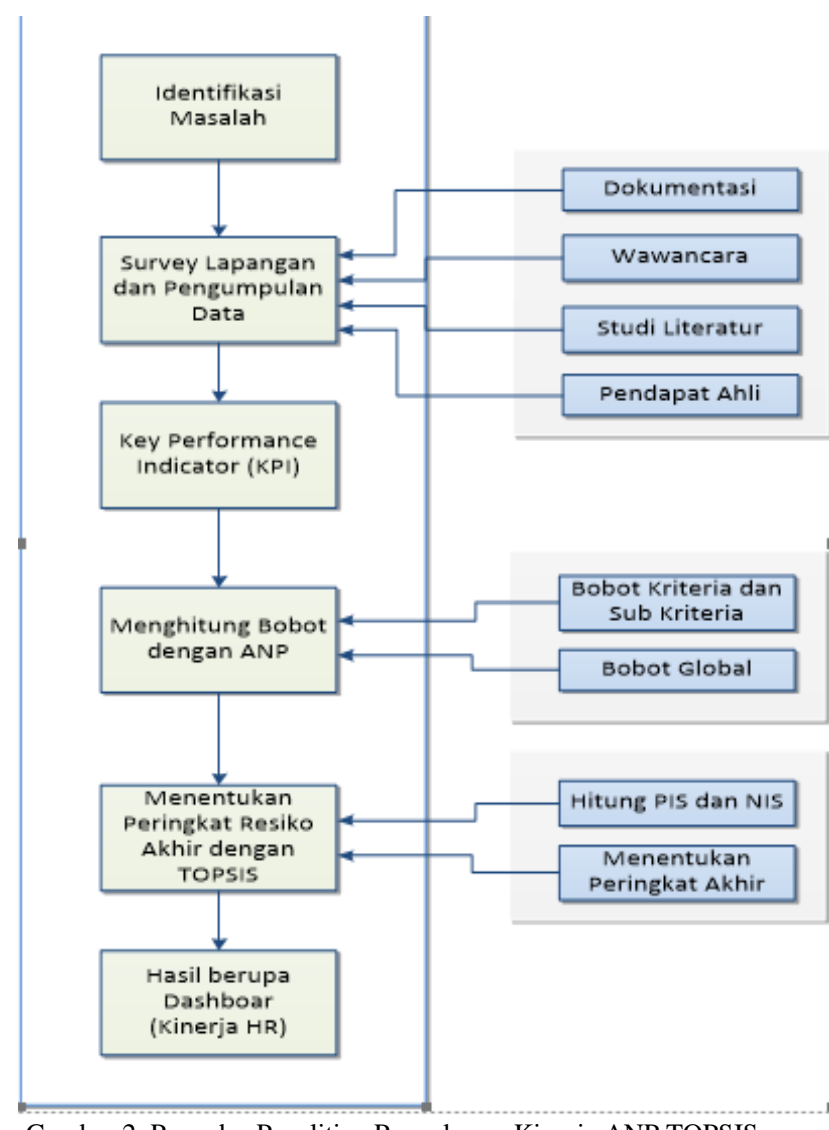

Gambar 2. Prosedur Penelitian Pengukuran Kinerja ANP TOPSIS

Tahap lainnya yang dilakukan dalam penelitian ini yaitu penilaian terhadap KPI yang digunakan sebagai kriteria dan penilaian terhadap alternatif yang dilakukan oleh responden dengan menggunakan kuesioner. Pada tahap ini, responden diminta untuk menentukan tingkat kepentingan dari masing-masing kriteria. Adapun kriteria dapat dipengaruhi oleh subkriteria lain. Untuk memperoleh nilai dari kuesioner yang dibuat digunakan metode Analytic Network Process (ANP), Nilai numerik pada seluruh perbandingan diperoleh dari skala perbandingan 1 sampai 9 yang telah ditetapkan oleh Saaty (Saaty, 1999).

Selanjutnya kuesioner yang mengacu pada metode Technique for Order Preference by Similarity to an Ideal Solution (TOPSIS). Responden diminta untuk mengisi jawaban dari pertanyaan terhadap masing- masing atribut. Pada masing-masing pertanyaan disediakan lima pilihan kategori jawaban. Untuk menghindari subyektifitas jawaban responden maka digunakan metode dimana responden memilih salah satu dari 5 kategori yang ada dengan skala 1 sampai 5 (Shyur, 2006).

\section{Hasil dan Pembahasan}

\subsection{Hasil Penelitian}

Pada penelitian ini dihasilkan sebuah aplikasi web back end sistem. Back end sistem dikelola oleh administrator dalam manajemen kuesioner, manajemen konten, dan pengolahan data. Hasil pengolahan data adalah berupa identifikasi kategori key performance indicator dan kinerja human resources. Sistem pengukuran kinerja merupakan sistem yang menyajikan informasi tentang tingkat kinerja dari pegawai terhadap tanggung jawab pekerjaan dan atribut-atribut yang berpengaruh terhadap kinerjanya. Hasil dari sistem ini dapat dijadikan saran bagi perusahaan sebagai penyedia layanan dalam pengukuran kinerja sehingga lebih maksimal dalam memanajemen kinerja pada bagian pengadaan, prosuksi dan distribusi.

Sistem pengukuran kinerja dirancang dengan berorientasi objek programming. User pada sistem ini terdiri atas dua user yaitu administrator dan responden. Administrator menginput data-data pertanyaan tiap subkriteria yang akan digunakan. Pada sistem ini menggunakan KPI sebagai dasar acuan dalam menentukan kriteria kinerja pada Procurement Section. Dari setiap atribut masingmasing KPI dijadikan pertanyaan untuk responden. Pertanyaan-pertanyaan tersebut menjadi inputan oleh administrator.

Penerapan metode ANP untuk evaluasi kinerja diawali dari menganalisa validitas pengukuran kinerja menggunakan kriteria, yang bersumber dari KPI. Setiap kriteria akan saling mempengaruhi dan dipengaruhi terhadap kriteria yang lain. Untuk memperoleh tingkat kepentingan antar kriteria dibuat perbandingan berdasarkan penilaian dari pengambil keputusan dengan menilai tingkat kepentingan suatu elemen untuk menentukan bobot dari masing-masing KPI berdasarkan pertanyaanpertanyaan yang telah diinputkan oleh administrator sebelumnya. Perbandingan berpasangan dari tingkat kepentingan menghasilkan matriks yang akan digunakan untuk membentuk sebuah supermatriks dengan menggabungkan seluruh matriks yang telah dibuat sebelumnya. Hasil analisis mengunakan ANP menghasilkan bobot normal yang nantinya akan digunakan untuk perhitungan TOPSIS yang disajikan dalam bentuk tabel pada Tabel 4 . 
Tabel 4. Limit Supermatriks

\begin{tabular}{ccccccccc}
\hline LS & A1 & A2 & A3 & A4 & A5 & A6 & A7 & A8 \\
\hline A1 & 0.0103 & 0.0103 & 0.0103 & 0.0103 & 0.0103 & 0.0103 & 0.0103 & 0.0103 \\
A2 & 0.0254 & 0.0254 & 0.0254 & 0.0254 & 0.0254 & 0.0254 & 0.0254 & 0.0254 \\
A3 & 0.0883 & 0.0883 & 0.0883 & 0.0883 & 0.0883 & 0.0883 & 0.0883 & 0.0883 \\
A4 & 0.1714 & 0.1714 & 0.1714 & 0.1714 & 0.1714 & 0.1714 & 0.1714 & 0.1714 \\
A5 & 0.0905 & 0.0905 & 0.0905 & 0.0905 & 0.0905 & 0.0905 & 0.0905 & 0.0905 \\
A6 & 0.2007 & 0.2007 & 0.2007 & 0.2007 & 0.2007 & 0.2007 & 0.2007 & 0.2007 \\
A7 & 0.2927 & 0.2927 & 0.2927 & 0.2927 & 0.2927 & 0.2927 & 0.2927 & 0.2927 \\
A8 & 0.1208 & 0.1208 & 0.1208 & 0.1208 & 0.1208 & 0.1208 & 0.1208 & 0.1208 \\
\hline
\end{tabular}

Tabel 4 diatas menunjukan nilai dari bobot normal dari masing-masing KPI yang dihasilkan dari perhitungan supermatriks, yang setiap kolomnya mempunyai nilai yang sama. Pada tabel 4 dari limit supermatriks diatas menunjukan nilai tertinggi adalah $(0,2927)$ nilai ini mengindikasikan bahwa memilih pemasok yang dekat dengan pabrik (A7) merupakan hal terpenting dalam Procurement Section, sementara nilai terendah adalah $(0,0103)$ dimana menentukan kualitas barang yang baik (A1) merupakan aspek yang mempunyai nilai terendah dalam Procurement Section.

Metode TOPSIS digunakan untuk melakukan perangkingan berdasarkan bobot yang diperoleh dari perhitungan ANP. Sebelumnya responden mengisi kuesioner untuk menentukan kinerja dari pegawai berdasarkan pertanyaan yang diberikan. Hasil jawaban dari responden dianalisis menggunakan analisisTOPSIS. Prosedur dari analisis TOPSIS adalah normalisasi jawaban responden, mengalikan hasil normalisasi dengan bobot normal yang diperoleh dari perhitungan ANP sehingga menghasilkan matriks keputusan terbobot, menentukan solusi ideal positif dan solusi ideal negatif berdasarkan nilai terbesar dan terkecil dari setiap subkriteria, menaikan pangkat dari solusi ideal positif dan negatif lalu menjumlahkannya sehingga diperoleh jarak solusi ideal positif dan negatif, serta menentukan nilai preferensi berdasarkan jarak ideal positif dan negatif.

Hasil TOPSIS diperoleh informasi bahwa masingmasing pegawai mempunyai nilai akhir berdasarkan penilaian dari responden yang mana dapat menjadi rekomendasi perbaikan kinerja di masa yang akan datang. Selain itu, hasil akhir dari evaluasi ini adalah tingkat kinerjamasing-masing pegawai yang telah dirangking. Output dari sistem ini adalah perangkingan human resources yang ditampilkan dalam bentuk tabel dan grafik. Hasil analisis TOPSIS menunjukan nilai nilai preferensi dari setiap pegawai secara keseluruhan yang disajikan dalam bentuk grafik pada gambar 3 dan diurutkan dari yang tertinggi sampai yang terendah.

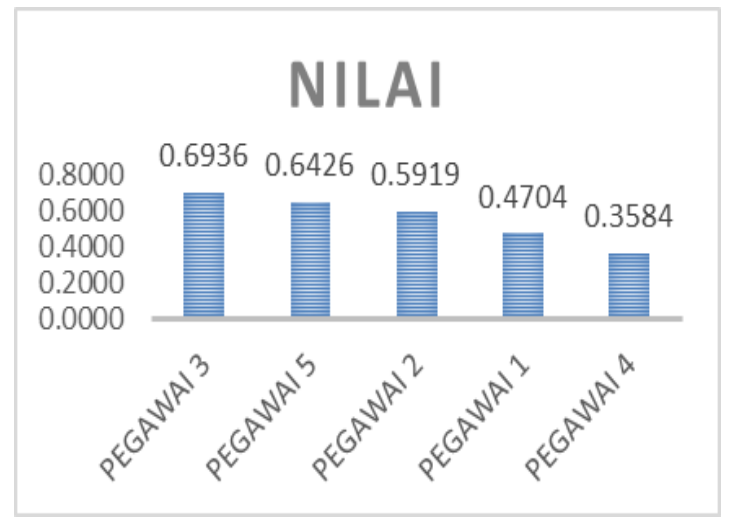

Gambar 3. Hasil Perangkingan

Dari grafik pada gambar 3 diatas jelas terlihat total terbesar sampai terkecil dari lima alternatif kategori yang ada dari Procurement Sectionpada perusahaan. Sehingga diperoleh nilai dari pegawai 3 adalah 0,6936 yang merupakan nilai tertinggi dan pegawai 4 adalah 0,3584 mendapatkan nilai terendah diantara semua pegawai. Dari hasil yang diperoleh menunjukan bahwa selisih data aktual dari perhitungan yang dilakukan dan data hasil rekomendasi sistem pengambilan keputusan dengan menggunakan metode ANP dan TOPSIS menunjukan bahwa tidak terdapat perbedaan sehingga sistem ini dapat digunakan perusahaan untuk melakukan pengukuran kinerja human resources.

\subsection{Pembahasan}

Ada 30 orang responden dari setiap departemen yang telah mengisi kuesioner berdasarkan penilaian mereka terhadap alternatif dilapangan menggunakan kuesioner yang telah diberikan. Hasil yang diperoleh dari pengolahan data dengan menggunakan analisis Analytic Network Process (ANP) dan Technique for Order Preference by Similarity to an Ideal Solution (TOPSIS) untuk mengukur kinerja human resources pada Procurement Section menunjukan bahwa kedua metode ini dapat digunakan untuk membangun sistem pengukuran kinerja dengan mengacu pada kriteria yang disusun sebelumnya.

Dari hasil perhitungan pertama sampai terakhir pada sistem menunjukan bahwa tingkat keakuratan 
sistem yang dibuat sama dengan data yang telah disusun dan dihitung secara manual sebelumnya. Ini membuktikan bahwa sistem ini dapat dan layak digunakan untuk mengukur kinerja human resources.

Beberapa faktor atau kriteria yang saling berpengaruh satu sama lainnya di identifikasi. Adapun saling berpengaruhnya kriteria dengan kriteria lainnya diperoleh dengan menentukan terlebih dahulu saling keterkaitan antara kriteria itu, sehingga diperoleh struktur jaringan dari perbandingan antar kriteria.

Adapun struktur jaringan yang dibentuk berdasarkan saling keterkaitan antar subkriteria pada bagian pengadaan dapat dilihat pada Gambar 4.

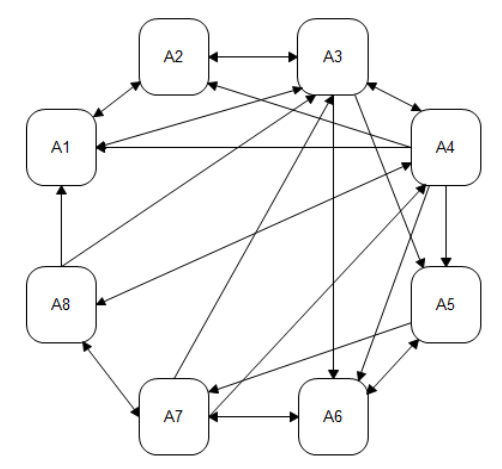

Gambar 4. Struktur Jaringan Procurement Section

Gambar 4 menunjukan bahwa pada Procurement Section terdapat delapan kriteria. Anak panah menunjukan terdapat hubungan pengaruh antara kriteria satu dengan kriteria lainnya. Hubungan pengaruh ini digunakan untuk menentukan supermatriks dari perbandingan berpasangan yang diperoleh dari hubungan pengaruh yang ada.

Tahap selanjutnya adalah menentukan matriks perbandingan berpasangan. Pada tahap ini diformulasikan hubungan antar kriteria, dimana setiap kriteria digunakan sebagai faktor kontrol untuk menentukan matriks perbandingan berpasangan. Setelah memformulasikan hubungan saling ketergantungan, perbandingan berpasangan dilakukan dengan mengacu ke semua faktor yang mempunyai pengaruh terhadap faktor lain pada jaringan.

Pada Tabel 5 berikut dapat dilihat contoh matriks perbandingan berpasangan dengan menentukan kualitas bahan yang baik (A1) sebagai faktor kontrol yang digunakan untuk melihat pengaruhnya terhadap faktor/subkriteria lainya.

Tabel 5 menunjukkan bahwa kriteria A3 dan A8 merupakan kriteria yang paling berpengaruh terhadap A1, dengan nilai prioritas sebesar 0.37500 diikuti oleh A2 dan A4, dengan nilai prioritas sebesar 0.12500 . Setelah vektor prioritas atau eigen vector diperoleh dari perbandingan berpasangan antara seluruh subkriteria, maka tahap selanjutnya adalah membuat supermatrils.
Tabel 5. Matriks perbandingan berpasangan dengan menentukan kualitas bahan yang baik(A1) sebagaifaktor kontrol di Procurement Section

\begin{tabular}{cccccc}
\hline & & & & & Vektor \\
$\mathrm{A} 1$ & $\mathrm{~A} 2$ & $\mathrm{~A} 3$ & $\mathrm{~A} 4$ & $\mathrm{~A} 8$ & Priority \\
\hline $\mathrm{A} 2$ & 1 & $1 / 3$ & 1 & $1 / 3$ & 0.12500 \\
$\mathrm{~A} 3$ & 3.0000 & 1 & 3 & 1 & 0.37500 \\
$\mathrm{~A} 4$ & 1.0000 & 0.3333 & 1 & $1 / 3$ & 0.12500 \\
$\mathrm{~A} 8$ & 3.0000 & 1.0000 & 3.0000 & 1 & 0.37500 \\
Jumlah & 8.0000 & 2.6667 & 8.0000 & 2.6667 & 1.0000 \\
\hline
\end{tabular}

Langkah pertama yaitu membuat supermatriks tak terbobot yang merupakan supermatriks yang diambil dari vektor prioritas yang diperoleh dari matriks perbandingan berpasangan dari elemen-elemen yang dihitung. Setelah supermatriks tak terbobot didapat maka kita akan menentukan supermatriks tak terbobot. Pada tahap supermatriks terbobot ini, merupakan supermatriks yang dihasilkan dengan menormalisasikan semua elemen yang ada di dalam dari unweighted supermatrix dengan bobot kriteria yang diperoleh dari matriks perbandingan antar kriteria yang sesuai. Sehingga dari hasil perkalian tersebut akan diperoleh supermatriks terbobot yang setiap kolomnya adalah stokastik yang berjumlah satu. Lalu, Limiting Supermatrix diperoleh dengan cara memangkat supermatriks terbobot dengan angka tertinggi agar kolomnya memiliki nilai yang sama. Dari perhitungan limit supermatriks maka diperoleh bobot normal dari masing-masing kriteria yang berjumlah satu. Bobot normal ini yang nantinya akan digunakan pada langkah TOPSIS dalam melakukan perangkingan.Bobot normal yang diperoleh dari masing-masing Limiting supermatrix dari ketiga bagian tersebut yang nantinya digunakan untuk melakukan perangkingan di Procurement Section yang ada dalam perusahaan. Sehingga setiap bagian tersebut memiliki bobot pengukuran yang berbedabeda satu sama lainnya. Adapun nilai bobot dari masing-masing kriteria adalah 0.0103288, 0.0253610, $0.0882561, \quad 0.1713807,0.0905415,0.2006541$, $0.2927154,0.1207624$. Setelah proses pembobotan menggunakan ANP selesai maka tahap selanjutnya adalah perangkingan dengan menggunakan metode TOPSIS. Pengolahan data dengan menggunakan TOPSIS diawali dengan input Tabel Keputusan dari setiap kriteria pada tiap-tiap alternatif yang diperoleh dari hasil kuesioner. Proses metode TOPSIS dilanjutkan dengan pembobotan pada matriks yang telah ternormalisasi. Elemen dari normalisasi matriks keputusan dikalikan dengan bobot kriteria (yang dihitung pada proses ANP) sehingga diperoleh normalisasi matriks keputusan terbobot. Berikut adalah tabel bobot kriteria yang didapat dari perhitungan ANP. Solusi ideal positif dan solusi ideal negatif diperoleh berdasarkan matriks normalisasi terbobot. Elemen dari $\mathrm{A}+$ pada tabel solusi ideal positif dan solusi ideal negatif adalah nilai tertinggi dari masing-masing kolom pada Tabel Normalisasi 
Matriks Keputusan Terbobot, sedangkan elemen dari $\mathrm{A}^{-}$pada tabel solusi ideal positif dan solusi ideal negatif adalah nilai terendah dari masing-masing kolom (Tabel 6).

Tabel 6. Normalisasi Matriks Keputusan

\begin{tabular}{ccccccccc}
\hline & \multicolumn{1}{c}{ Kriteria } \\
\cline { 2 - 9 } Alternatif & B1 & B2 & B3 & B4 & B5 & B6 & B7 & B8 \\
\hline PEGAWAI 1 & 0.4808 & 0.4449 & 0.4689 & 0.3844 & 0.4808 & 0.4449 & 0.4689 & 0.3844 \\
PEGAWAI 2 & 0.4274 & 0.4624 & 0.4211 & 0.4964 & 0.4274 & 0.4624 & 0.4211 & 0.4964 \\
PEGAWAI 3 & 0.4323 & 0.4755 & 0.4602 & 0.4526 & 0.4323 & 0.4755 & 0.4602 & 0.4526 \\
PEGAWAI 4 & 0.4468 & 0.4100 & 0.4037 & 0.4574 & 0.4468 & 0.4100 & 0.4037 & 0.4574 \\
PEGAWAI 5 & 0.4468 & 0.4406 & 0.4775 & 0.4380 & 0.4468 & 0.4406 & 0.4775 & 0.4380 \\
\hline
\end{tabular}

Pada langkah selanjutnya adalah menentukan jarak setiap alternatif terhadap solusi ideal positif dan jarak setiap alternatif terhadap solusi ideal negatif sehingga menghasilkan tabel jarak solusi positif dan negatif.

Nilai preferensi adalah nilai akhir yang menjadi patokan dalam menentukan peringkat pada semua alternatif yang ada. Nilai preferensi pada suatu alternatif merupakan perbandingan antara jarak dari solusi ideal negatif dan jumlah jarak terhadap solusi ideal positif.

Tabel 7. Nilai Perangkingan Akhir

\begin{tabular}{cccc}
\hline No & \multicolumn{3}{c}{ Rangking } \\
\hline 1 & PEGAWAI 3 & V3 & 0.6936 \\
2 & PEGAWAI 5 & V5 & 0.6426 \\
3 & PEGAWAI 2 & V2 & 0.5919 \\
4 & PEGAWAI 1 & V1 & 0.4704 \\
5 & PEGAWAI 4 & V4 & 0.3584 \\
\hline
\end{tabular}

Penilaian pada Procurement Section menunjukan hasil dari nilai akhir adalah rangking dari setiap alternatif yang diurutkan dari alternatif yang memiliki nilai terbesar sampai alternatif yang memiliki nilai terkecil. Nilai pegawai 3 merupakan nilai terbesar dengan 0,6936 disusul pegawai 5 dengan 0,6426, pegawai dengan 0,5919, pegawai 1 dengan 0,4704 dan pegawai 4 dengan 0,3584. Hal ini juga ditunjukan dengan grafik nilai dari setiap pegawai. Dengan demikian dapat disimpulkan bahwa kinerja pegawai 3 adalah yang tertinggi dibandingkan kinerja pegawai lainnya menurut dari responden yang menilai.

\section{Kesimpulan}

Berdasarkan hasil penelitian dan pembahasan mengenai penerapan metode ANP dan TOPSIS pengukuran kinerja Human Resources pada Procurement Section maka didapat kesimpulan bahwa penerapan metode ANP dan TOPSIS pada evaluasikinerja human resources dapat mengidentifikasi penilaian terhadap pegawai berdasarkan kategori KPI. KPI yang digunakan sebagai parameter pengukuran mempunyai pengaruh terhadap kinerja human resources sebagai penilaian bobot normal. Hasil analisis pada studi kasus diperoleh bahwa penilaian terhadap pegawai pada Procurement Section mempunyai nilai yang berbeda sesuai dengan bobot yang diperoleh dari perbandingan berpasangan antar subkriteria. Untuk mendapat hasil pengambilan keputusan yang sesuai, seorang yang memahami tentang permasalahan sangat ditekankan, terutama dalam menentukan nilai inputan yang ada, sehingga diperoleh nilai yang sesuai dengan sub kriteria.

\section{Daftar Pustaka}

Behzadiana, M., Otaghsara, S.K., Yazdani, M., Ignatius, J, 2012. A state-of the-art survey of TOPSIS applications, Expert Systems with Applications 39 (2012) 13051-13069.

Buller, P.F. and McEvoy, G.M., 2012. Strategy Human Resource Management and Performance: Sharpening Line of Sight, Human Resource Management Review 22, 43-56.

Cai, J., Liu, X., Xiao, Z., dan Liu, J, 2009. Improving Supply Chain Performance Management: a Systematic Approach to Analyzing Iterative KPI Accomplishment, Decision Support Systems 46, 512-521.

Kusumadewi, S., Hartati, S., Harjoko, A., Wardoyo, R., 2006. Fuzzy Multi Attribute Decision Making (Fuzzy MADM), Graha Ilmu, Yogyakarta.

Parmenter, D, 2007. Developing, Implementing and Using Winning KPIs, John Wiley \& Sons.

Saaty, T.L., 1999. Fundamentals of the Analytic Network Process. ISAHP Japan, pp. 12-14.

Saaty, T.L., 2008. Decision making with the analytic hierarchy process, Int. J. Services Sciences, Vol. 1, No. 1.

Shyur, H.J., 2006. Cots Evaluation Using Modified TOPSIS and ANP, Applied Mathematics and Computation 177, 251-259.

Silva, L.C., dan Costa, A.P.C.S, 2013. Decision Model for Allocating Human Resources In 
Information System Projects, International Journal of Project Management 31 (2013) 100-108.

Wu, C.S., Lin, C.T., dan Lee, C., 2010. Optimal Marketing Strategy: A Decision-Making with ANP and TOPSIS, Int. J. Production Economics 127, 190-196.
Zhu, X., Wang, F., Liang, C., Li, J.,dan Sun, X., 2012. Quality credit evaluation based on TOPSIS: Evidence From Air-Conditioning Market In China, Procedia Computer Science, 9, 1256 1262. 